\title{
Profile and geographic distribution of reported cases of visceral leishmaniasis in Campo Grande, State of Mato Grosso do Sul, Brazil, from 2002 to 2009
}

\author{
Júlia Cristina Maksoud Brazuna ${ }^{[1],[2]}$, Elaine Araujo e Silva ${ }^{[2]}$, Júlio Maksoud Brazuna ${ }^{[3]}$, lara Helena Domingos ${ }^{[2]}$, \\ Neuma Chaves ${ }^{[2]}$, Michael Robin Honer ${ }^{[4]}$, Valter Joost van Onselen ${ }^{[1]}$ and Ana Lúcia Lyrio de Oliveira ${ }^{[1],[2]}$
}

\begin{abstract}
[1]. Programa de Pós-Graduação em Doenças Infecciosas e Parasitárias, Universidade Federal de Mato Grosso do Sul, Campo Grande, MS. [2]. Centro de Controle de Zoonoses, Secretaria Municipal de Saúde Pública, Campo Grande, MS. [3]. Universidade para o Desenvolvimento do Estado e da Região do Pantanal, Campo Grande, MS. [4]. Programa de Pós-Graduação em Biotecnologia, Universidade Católica Dom Bosco, Campo Grande, MS.
\end{abstract}

\section{ABSTRACT}

Introduction: This study sought to describe the profile and geographic distribution of reported cases of visceral leishmaniasis (VL) in the City of Campo Grande, State of Mato Grosso do Sul (MS), Brazil, from 2002 to 2009. Methods: Human data were collected from the Brazilian National Information System for Notifiable Diseases. Canine cases and entomological data were obtained from the Information Service for Canine Visceral Leishmaniasis Control/Campo Grande, MS. Results: A total of 951 records from 2002 to 2009 were investigated. The number of reported cases of VL in males was significantly higher $(p<0.0001)$ than that in females. The higher frequency observed among males was associated with age $(p<0.0001)$, which increased in individuals aged 40 years and older. The overall fatality rate was $7.4 \%$. Entomological surveys conducted in 2006, 2007, and 2009 showed the insect vector Lutzomyia longipalpis to be present in all urban regions of the county. Conclusions: VL cases in humans and dogs, as well as in vectors, occurs in all urban regions of Campo Grande. Despite not observing tendencies of increase or reduction in the incidence of the disease due to aging, the major incidence in men is higher in those aged 40 years or above.

Keywords: Visceral leishmaniasis. Epidemiology. Risk factors.

\section{INTRODUCTION}

Visceral leishmaniasis (VL), a potentially fatal parasitic zoonosis, is a frequently occurring disease in the Indian subcontinent, East Africa, and South America ${ }^{1}$. In Brazil, VL is caused by Leishmania infantum (syn. L. chagasi). Fatal if untreated, VL has a wide clinical spectrum of signs and symptoms. These can be moderate to severe and are often characterized by fever, pallor, and hepatosplenomegaly, sometimes including diarrhea and/or nonproductive cough, features that are often shared with other infectious processes ${ }^{2}$, including human immunodeficiency virus (HIV), malaria, diarrhea caused by other etiologies, hepatitis, and other causes.

Visceral leishmaniasis is transmitted by infected female sandflies, particularly Lutzomyia longipalpis, dipterous insects of the family Psychodidae ${ }^{3}$. In a localized outbreak of the disease in the county of Corumbá, State of Mato Grosso do Sul (MS), L. cruzi was identified as the main vector species ${ }^{4}$.

Visceral leishmaniasis diagnosis has been largely based on microscopic examination of thin smears of bone marrow, although serological and molecular methods constitute less invasive alternatives currently in use. ${ }^{1}$

A number of factors facilitate VL transmission. Poor housing and sanitation, often resulting from fast, unplanned population growth, particularly in developing countries, provide a favorable environment for transmission of infectious and parasitic diseases ${ }^{5}$.

Address to: Dra. Júlia Cristina Maksoud Brazuna. CCZ/Secretaria Municipal de Saúde Pública. Av. Senador Filinto Muller 1601, 79074-460 Campo Grande, MS, Brasil.

Phone: 5567 3313-5018; Fax 5567 3314-9501

e-mail: maksoudbrazuna@gmail.com

Received in 29/09/2011

Accepted in 19/04/2012
Mato Grosso do Sul, in southwestern Brazil, has recently undergone environmental changes such as the construction of a gas pipeline and the destruction of cerrado vegetation that may have played a role in the spread of vectors. In Campo Grande, the state capital, the laying down of avenues bordering water courses and the clearing of native vegetation to make way for low-income housing developments have had a major impact on the environment. The high ratio of $L$. longipalpis occurrence relative to other phlebotomine species in areas of human and canine leishmaniasis cases reflects the insect's role as a VL vector in the Brazil ${ }^{6}$. The disease gained endemic status with the first reported autochthonous cases in dogs in 1998 and humans in 2002.

This study sought to describe the profile and geographic distribution of reported cases of VL in Campo Grande, MS, Brazil between 2002 and 2009.

\section{METHODS}

Campo Grande (2026'34"S, 5438'47"W) covers 8,118.4km² of the central portion of MS, accounting for $2.3 \%$ of the state's area. The urban area of Campo Grande is formally divided into 7 regions-Anhanduizinho, Bandeira, Centro, Imbirussu, Lagoa, Prosa, and Segredo ${ }^{8}$.

Retrospective data of human VL cases from January 2002 to December 2009 were collected from the records of the Brazilian National Information System for Notifiable Diseases (Sistema de Informação de Agravos de Notificação [SINAN]), managed by the Municipal Health Office of Campo Grande (Secretaria Municipal de Saúde Pública [SESAU]). Data collection ended in September 2010. The following variables were analyzed for all reported autochthonous cases: a) personal data: age, gender, county region of residence; b) 
diagnostic method: enzyme-linked immunosorbent assay (ELISA), indirect fluorescent antibody test (IFAT), direct parasitological examination; c) symptoms or clinical signs: fever, splenomegaly, hepatomegaly, weakness, weight loss, and cough and/or diarrhea. Coinfection with human immunodeficiency virus; and d) case outcome: death or treatment.

Two factors related to transmission of $V L$ to humans were assessed: a) visceral leishmaniasis in dogs: the number of occurrences in each urban region was obtained from the Information Service for Canine Visceral Leishmaniasis Control (SCL), managed by the county's Center for Zoonosis Control (Centro de Controle de Zoonoses [CCZ]). Data from the SCL's serosurvey records were limited to 2007-2009, given the inconsistency of records prior to this period. The laboratory methods for VL diagnosis in dogs included screening by ELISA and IFAT for confirmation of disease. The kits were provided by the Biomanguinhos laboratory (Fundação Oswaldo Cruz, Rio de Janeiro, Brazil); and b) vector presence: data regarding $L$. longipalpis presence were collected from entomological surveys conducted in 2006, 2007, and 2009. In all districts of each urban region, sandflies were collected using 2 traps per household ( 1 indoors, 1 outdoors). For 3 consecutive nights, the traps were installed at dusk and collected in the morning. Household selection took into account the presence of plants (trees and shrubs), accumulated organic matter, and domestic animals (dogs and chickens)-elements suggestive of vector presence.

Descriptive statistical analysis was performed, and frequencies were calculated for the variables. The statistical significance of the association between variables was determined using the chi-squared test, considering a type I error probability of $1 \%(\alpha=0.01)^{9}$.

\section{Ethical considerations}

The study was approved by the Research Ethics Committee of the Universidade Federal de Mato Grosso do Sul (permit 1212, obtained on June 27,2008 ).

\section{RESULTS}

From January 1, 2002, to December 31, 2009, a total of 951 autochthonous cases of VL were reported in Campo Grande $(98.9 \%$ or 941 cases in the urban area, $0.5 \%$ or 5 cases in the rural districts, and $0.5 \%$ or 5 cases without records for location).

The distribution of human cases by region is shown in Figure 1.

The records of VL cases at the SESAU began in 2002, peaking in 2006 during the period investigated (Table 1). Cases were diagnosed and reported in every month during the study period, with higher rates observed from September to March. September had the highest rate, which was $10.8 \%$ throughout the period of the study.

A significantly higher number of cases were reported in males $(p<0.0001)$ than in females. The higher rates observed among males were associated with age $(p<0.0001)$, which increased in individuals aged 40 years and older (Table 2).

Over a third of cases occurred in patients younger than 10 years of age. Slightly less than half of the patients were under 20 years of age (Table 2). Although the number of reported cases differed significantly $(p<0.0001)$ between age groups, an increase or reduction in the proportion of individuals in extreme age ranges was not observed.

The overall fatality rate was $7.4 \%$ during the study period, where the referred rate for males is $8,9 \%$, and for females is $4,5 \%$, with higher values among patients aged 60 years and older (Table 2).

In most cases (730/951 or $76.8 \%)$, diagnosis was based on parasitological examination, with $79.5 \%$ of individuals testing $(580 / 730)$ positive. IFAT was performed for $45.7 \%$ of cases (435/951), of which $85.8 \%$ (373/435) were positive. ELISA was performed only from 2002-2006, for $7.6 \%(72 / 951)$ of cases, of which $18.1 \%$ (13/72) were positive. In cases not subjected to laboratory testing, diagnosis was based on therapeutic response.

The signs and symptoms described in the 951 records included fever (95.3\%), splenomegaly (83.6\%), hepatomegaly $(75.8 \%)$, weakness $(74.1 \%)$, weight loss (72.2\%), and cough and/or diarrhea (50.68\%). Co-infection with human immunodeficiency virus occurred in $7.1 \%$ of cases.

From 2007 to 2009, a total of 45,873 cases of American VL (AVL) were detected in 326,217 dogs across all urban regions of the city, 2 of which (Anhanduizinho and Lagoa) jointly accounted for $42 \%$ of canine cases (Figure 1).

The insect vector was found to have spread to all urban regions, as shown by capture of $L$. longipalpis specimens in all 3 entomological surveys conducted in 2006, 2007, and 2009 (Table 3).
FIGURE 1 - Geographical distribution of the number of notified visceral leishmaniasis cases and cumulative incidence of VL in 8 years, Campo Grande, Mato Grosso do Sul, Brazil, 2002-2009.

VL: visceral leishmaniasis; I: rate per 10,000 inhabitants; N: number of cases. 
TABLE 1 - Reported autochthonous cases and incidence of visceral leishmaniasis, by urban region of residence in Campo Grande, Mato Grosso do Sul, Brazil, 2002-2009.

\begin{tabular}{|c|c|c|c|c|c|c|c|c|c|c|c|c|c|c|c|c|}
\hline \multirow[b]{3}{*}{ Urban region } & \multicolumn{16}{|c|}{ Year } \\
\hline & \multicolumn{2}{|c|}{2002} & \multicolumn{2}{|c|}{2003} & \multicolumn{2}{|c|}{2004} & \multicolumn{2}{|c|}{2005} & \multicolumn{2}{|c|}{2006} & \multicolumn{2}{|c|}{2007} & \multicolumn{2}{|c|}{2008} & \multicolumn{2}{|c|}{2009} \\
\hline & $\mathbf{N}$ & I & $\mathbf{N}$ & 1 & $\mathbf{N}$ & I & $\mathbf{N}$ & I & $\mathbf{N}$ & 1 & $\mathbf{N}$ & 1 & $\mathbf{N}$ & I & $\mathbf{N}$ & I \\
\hline Anhanduizinho & 8 & 5.0 & 36 & 22.1 & 44 & 26.5 & 43 & 24.8 & 47 & 26.6 & 39 & 23.1 & 39 & 22.2 & 22 & 12.4 \\
\hline Bandeira & 1 & 1.0 & 5 & 4.9 & 9 & 8.6 & 10 & 9.2 & 14 & 12.6 & 19 & 18.4 & 14 & 13.0 & 3 & 2.8 \\
\hline Centro & 2 & 2.5 & 15 & 18.6 & 14 & 17.1 & 6 & 7.0 & 11 & 12.5 & 8 & 10.9 & 5 & 6.5 & 7 & 9.0 \\
\hline Imbirussu & 2 & 2.2 & 13 & 13.6 & 23 & 23.7 & 29 & 28.6 & 19 & 18.4 & 11 & 11.5 & 28 & 28.1 & 16 & 15.9 \\
\hline Lagoa & 3 & 3.0 & 14 & 13.4 & 20 & 18.8 & 46 & 41.5 & 41 & 36.2 & 24 & 22.9 & 20 & 18.3 & 17 & 15.4 \\
\hline Prosa & 1 & 1.6 & 5 & 8.0 & 6 & 9.5 & 9 & 13.6 & 16 & 23.7 & 23 & 34.3 & 14 & 20.1 & 13 & 18.5 \\
\hline Segredo & 2 & 2.3 & 9 & 10.2 & 12 & 13.4 & 12 & 12.9 & 13 & 13.7 & 13 & 13.9 & 23 & 23.7 & 23 & 23.3 \\
\hline Total & 19 & 3.2 & 97 & 13.9 & 128 & 18.2 & 155 & 21.1 & 161 & 21.6 & 137 & 19.4 & 143 & 19.3 & 101 & 13.4 \\
\hline
\end{tabular}

N: number of cases; I: incidence rate per 100,000 inhabitants.

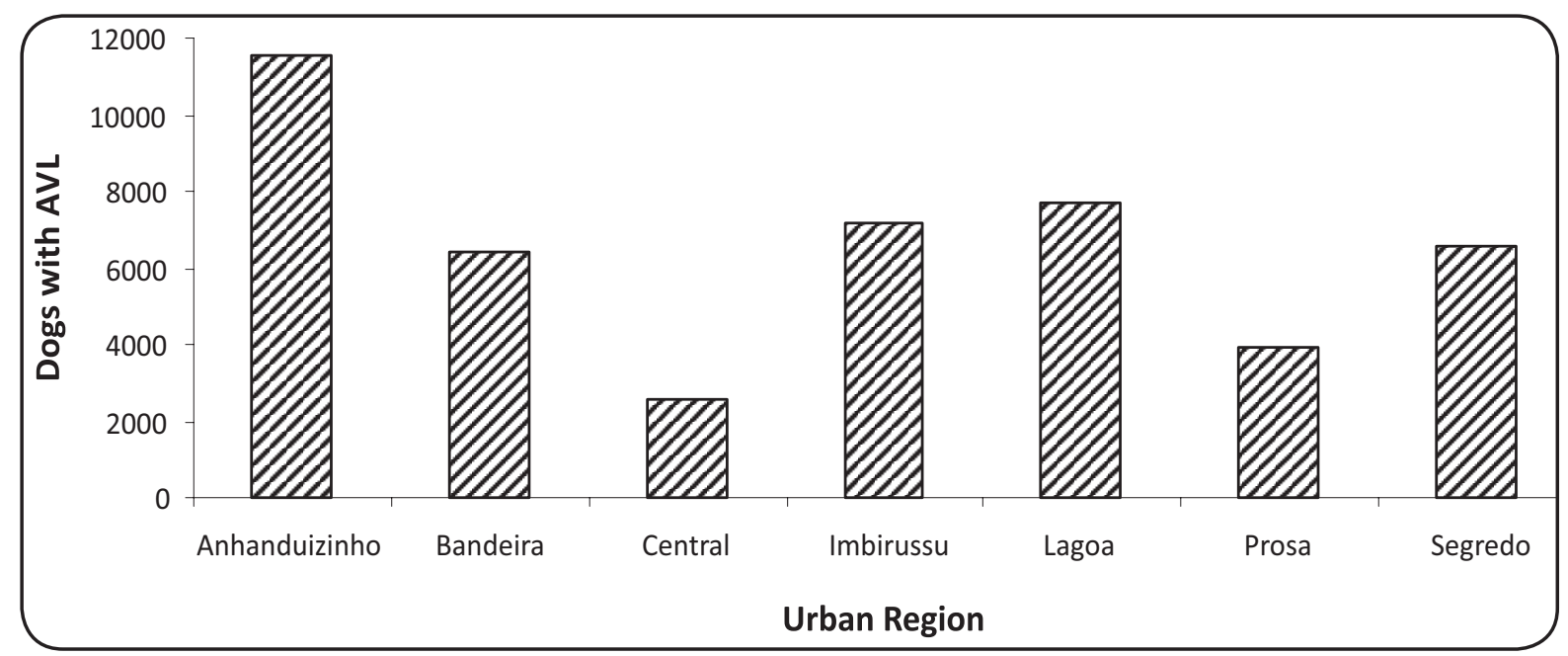

FIGURE 2 - American visceral leishmaniasis cases in dogs, by urban region in Campo Grande, Mato Grosso do Sul, Brazil, $2007-2009$.

AVL: American visceral leishmaniasis.

TABLE 2 - Number of cases, deaths, cumulative incidence and case fatality rates of visceral leishmaniasis, by age range and gender in Campo Grande, Mato Grosso do Sul, Brazil, from 2002-2009.

\begin{tabular}{|c|c|c|c|c|c|c|c|c|c|c|c|c|}
\hline \multirow[b]{4}{*}{ Age range (years) } & \multicolumn{12}{|c|}{ Gender } \\
\hline & \multicolumn{4}{|c|}{ males } & \multicolumn{4}{|c|}{ females } & \multicolumn{4}{|c|}{ total } \\
\hline & \multicolumn{2}{|c|}{ cases (incidence) } & \multicolumn{2}{|c|}{ deaths (fatality) } & \multicolumn{2}{|c|}{ cases (incidence) } & \multicolumn{2}{|c|}{ deaths (fatality) } & \multicolumn{2}{|c|}{ cases (incidence) } & \multicolumn{2}{|c|}{ deaths (fatality) } \\
\hline & $\mathbf{N}$ & I & $\mathbf{N}$ & $\%$ & $\mathbf{N}$ & I & $\mathbf{N}$ & $\%$ & $\mathbf{N}$ & I & $\mathbf{N}$ & $\%$ \\
\hline$<1$ & 45 & 94.0 & 6 & 13.3 & 30 & 65.7 & 0 & 0.0 & 75 & 80.2 & 6 & 8.0 \\
\hline $1|-| 4$ & 98 & 51.9 & 1 & 1.0 & 97 & 53.4 & 1 & 1.0 & 195 & 52.6 & 2 & 1.0 \\
\hline $5|-| 9$ & 60 & 22.3 & 1 & 1.7 & 40 & 15.3 & 0 & 0.0 & 100 & 18.9 & 1 & 1.0 \\
\hline $10|-| 19$ & 41 & 7.2 & 1 & 2.4 & 43 & 7.6 & 0 & 0.0 & 84 & 7.4 & 1 & 1.2 \\
\hline $20|-| 39$ & 147 & 15.3 & 7 & 4.8 & 72 & 6.9 & 3 & 4.2 & 219 & 11.0 & 10 & 4.6 \\
\hline $40|-| 59$ & 145 & 26.1 & 17 & 11.7 & 35 & 5.6 & 4 & 11.4 & 180 & 15.2 & 21 & 1.7 \\
\hline$\geq 60$ & 79 & 38.8 & 22 & 27.8 & 17 & 6.7 & 7 & 41.2 & 96 & 21.1 & 29 & 30.2 \\
\hline Not informed & \multicolumn{2}{|c|}{2} & \multicolumn{2}{|c|}{0} & \multicolumn{2}{|c|}{0} & \multicolumn{2}{|c|}{0} & \multicolumn{2}{|c|}{2} & \multicolumn{2}{|c|}{0} \\
\hline Total & 617 & 25.2 & 55 & 8.9 & 334 & 12.8 & 15 & 4.5 & 951 & 18.8 & 70 & 7.4 \\
\hline
\end{tabular}

N: number; I: incidence rate per 100,000 inhabitants from 2002 to 2009; \%: percentage. 
TABLE 3 - Number of households investigated and sandflies captured, by urban region in Campo Grande, Mato Grosso do Sul, Brazil, 2006-2009.

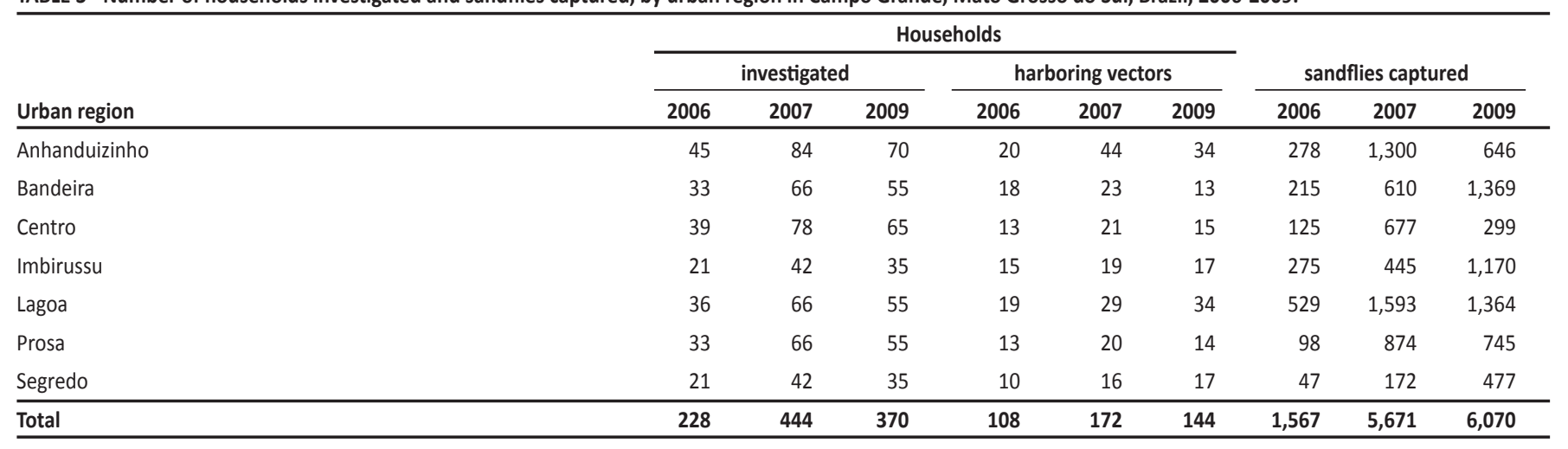

\section{DISCUSSION}

Drastic environmental changes caused by human activity have led some phlebotomine species to occupy urban habitats ${ }^{10}$. The literature reports the spread and urbanization of the VL vector, a process that has transformed several highly populated Brazilian centers into endemic areas for the disease. These centers include Santarém, Pará (PA), Corumbá, MS, Teresina, Piauí (PI), Natal, Rio Grande do Norte (RN), São Luis, Maranhão (MA), Fortaleza, Ceará (CE), Camaçari, Bahia (BA), and Belo Horizonte, Minas Gerais (MG) ${ }^{11-16}$.

With cases of VL occurring in all urban regions of Campo Grande since 2002, the disease can be considered endemic in the city. Anhanduizinho and Lagoa, the city's southwestern urban regions, have higher population densities and larger expanses of vegetation, favorable factors for the breeding of sandflies in addition to higher concentrations of dogs, the principal urban reservoirs of $L$. chagasi ${ }^{17}$. Higher concentrations of the vector in both regions have been reported for the 2003-2005 period $^{6}$. In the present investigation, larger numbers of seropositive dogs and greater proportions of households harboring sandflies were found in both regions, placing its residents at increased risk of contracting VL.

Although sandflies can be found virtually year round, entomological surveys have revealed higher vector densities during the months with higher temperatures and higher rainfall rates ${ }^{18,19}$. Vector density varies from region to region, depending on environmental factors and control measures.

The risk of transmission is highest from December to April, the wet period associated with an increased sandfly population ${ }^{6,20}$. Weather data for Campo Grande from 2002-2009 are typical of a tropical climate, with temperatures and rainfall rates favorable for the development of the VL vector ${ }^{8}$. Variation in incubation time, time elapsed from onset of symptoms to diagnosis, and records with incomplete or missing information regarding the estimated date of infection are some factors that, in conjunction, preclude deeper analysis of the monthly distribution of reported cases. Moreover, the month in which a case is reported does not necessarily correspond to the month of infection.

As a response to the increasing incidence of $A V L$, public health agents intervened in the regions with the most cases (Anhanduizinho, Lagoa, and Imbirussu) by using chemical control of vector insects, eliminating animal reservoirs, and implementing environmental management following the Health Ministry recommendations ${ }^{2}$. These initiatives could have contributed to stabilizing or quickly reducing the number of cases reported from 2007-2009 in the cited areas.

Higher VL incidence in males, also observed in other studies ${ }^{21-23}$, may be indicative of higher exposure to risk-associated environments (while not ruling out the possibility of differences between genders in defense mechanisms against $\mathrm{VL}$ ). This fact lends support to the hypothesis that infection is not limited to the household setting, as males and females are similarly distributed across urban regions.

Studies conducted in Três Lagoas, MS ${ }^{21}$, Brasília, Federal District ${ }^{24}$, and Várzea Grande, Mato Grosso ${ }^{25}$ reported a higher incidence of AVL in patients younger than 5 years, a feature possibly related to increased susceptibility to infection at an early age, when long-term immunity is developing ${ }^{21,24-26}$. This finding, also mirrored by the present study, is indicative of a transition from an epidemic to an endemic pattern of transmission.

Direct examination for parasites was also the method most often employed to confirm diagnosis in cases occurring in Recife, Pernambuco ${ }^{27}$ and Três Lagoas, MS. ${ }^{21}$ Reasons for the limited use of ELISA for human diagnosis include difficulties in standardization and constraints in sensitivity, specificity, availability, and $\operatorname{cost}^{27}$.

The symptoms exhibited by patients in the present investigation have also been reported in other studies conducted in Brazil ${ }^{21,28-30}$.

VL is the clinical form of leishmaniasis most associated with HIVinfected individuals. VL versus HIV co-infection, currently viewed as an emerging disease in several regions of the world, is spreading to Brazili ${ }^{31-33}$.

Death rates higher than those observed in the present study have been found in Natal, RN $(9 \%)^{34}$ and in the City of São Paulo $(9.3 \%)^{30}$. Early diagnosis and treatment are required if morbidity and mortality from VL are to be reduced, as early-treated patients are clinically cured in $98 \%$ of cases, ${ }^{34}$ while the fatality rate is near $95 \%$ in untreated cases $^{35}$.

There is no tendency toward either increase or reduction in $\mathrm{VL}$ incidence as the age of individuals increase.

\section{VL occurred predominantly in males in all age ranges.}

The higher incidence of leishmaniasis in men is elevated in the group aged 40 years or above. Fever, splenomegaly, hepatomegaly, weakness, and weight loss are frequent clinical signs in VL patients. 
Leishmaniasis cases in human and dogs as well as in vectors (sandflies, Lutzomyia longipalpis) occur in all urban regions of Campo Grande City.

\section{CONFLICT OF INTEREST}

The authors declare that there is no conflict of interest.

\section{ABSTRACT IN PORTUGUESE}

\section{Perfil e distribuição geográfica de casos notificados de leishmaniose visceral na Cidade de Campo Grande, Estado do Mato Grosso do Sul, Brasil, entre 2002 e 2009}

Introdução: O objetivo deste trabalho foi descrever o perfil e a distribuição geográfica de casos notificados de leishmaniose visceral, na Cidade de Campo Grande, Mato Grosso do Sul (MS), Brasil, entre os anos de 2002 e 2009. Métodos: Os dados de casos humanos foram obtidos a partir da Ficha de Notificação do Sistema Nacional de Agravos de Notificação. Os casos caninos e dados entomológicos foram obtidos do Sistema de Controle de Leishmaniose/Campo Grande, MS. Resultados: Foram notificados 951 casos de leishmaniose visceral entre 2002 e 2009. A ocorrência destes nos indivíduos do sexo masculino foi significativamente maior $(p<0,0001)$ do que nos do sexo feminino. Essa superioridade na frequência de notificações em homens associou-se à idade $(p<0,0001)$, sendo mais intensa nos indivíduos com idade igual ou superior a 40 anos. O coeficiente de letalidade foi de 7,4\%. O levantamento entomológico feito em 2006, 2007 e 2009 demonstrou dispersão do vetor em todas as regiões urbanas do município com captura de L. longipalpis nos três anos. Conclusões: Casos de LV em humanos e em cães assim como o vetor ocorrem em todas as regiões urbanas Campo Grande. Embora não haja tendência de aumento, nem de redução na incidência da doença à medida que a idade dos indivíduos aumenta, a superioridade na incidência em homens é maior no grupo de pessoas com idade igual ou superior a 40 anos.

Palavras-chaves: Leishmaniose visceral. Epidemiologia. Fatores de risco.

\section{REFERENCES}

1. Mondal S, Bhattacharya P, Ali N. Current diagnosis and treatment of visceral leishmaniasis. Expert Rev Anti Infect Ther 2010; 8:919-944.

2. Ministério da Saúde. Secretaria de Vigilância em Saúde. Departamento de Vigilância Epidemiológica. Manual de Vigilância e Controle da Leishmaniose Visceral. Brasília: Ministério da Saúde; 2006.

3. Gontijo CMF, Melo MN. Leishmaniose visceral no Brasil: quadro atual, desafios e perspectivas. Rev Bras Epidemiol 2004; 7:338-349.

4. Santos SO, Arias JR, Ribeiro AA, Hoffman MP, Freitas RA, Malacco MAE. Incrimination of Lutzomyia cruzi as a vector of american visceral leishmaniasis. Med Vet Entomol 1998; 12:315-317.

5. Desjeux P. The increase in risk factors for leishmaniasis worldwide. Trans R Soc Trop Med Hyg 2001; 95:239-243.

6. Silva EA, Andreotti R, Honer MR. Comportamento de Lutzomyia longipalpis, vetor principal da leishmaniose visceral americana, em Campo Grande, Estado do Mato Grosso do Sul. Rev Soc Bras Med Trop 2007; 40:420-425.

7. Prefeitura Municipal de Campo Grande. Coordenadoria de Vigilância em Saúde. Serviço de Vigilância Epidemiológica. SINAN. Relatórios SESAU-2002. Campo Grande: Secretaria Municipal de Saúde; 2005.

8. Prefeitura Municipal de Campo Grande. Perfil Sócio-Econômico de Campo Grande. Campo Grande: Instituto Municipal de Planejamento Urbano; 2008.
9. Sampaio IBM. Estatística aplicada à experimentação animal. $3^{\text {rd }}$ ed. Belo Horizonte: Fundação de Ensino e Pesquisa em Medicina Veterinária e Zootecnia, Belo Horizonte; 2007.

10. Rangel EF. Transmission of american cutaneous leishmaniasis in peridomestic foci in Rio de Janeiro State and other similar situation comparing with the classic epidemiology in Amazon Brazil. Proceedings from a research seminar Tdr Sarec, Stenungsund, Sweden. Vol. 2; p. 103110; 1995.

11. Marzochi MCA, Sabroza PC, Toledo LM, Marzochi KBF, Tramontano NC, Rangel Filho FB. Leishmaniose visceral na cidade do Rio de Janeiro - Brasil. Cad Saude Publica 1985; 1:5-17.

12. Genaro O, Costa CA, Williams P, Silva JE, Rocha NM, Lima SL, et al. Ocorrência de calazar em área urbana da Grande Belo Horizonte. Rev Soc Bras Med Trop 1990; 23:121.

13. Costa CHN, Pereira HF, Araújo MV. Epidemia de leishmaniose visceral no Estado do Piauí, Brasil, 1980-1986. Rev Saude Publica 1990; 24:361-372.

14. Tesh RB. Control of zoonotic visceral leishmaniasis: is it time to change stategies? Am J Trop Med Hyg 1995; 52:287-292.

15. Castro AG. Controle, diagnóstico e tratamento da leishmaniose visceral (calazar). Brasília: Fundação Nacional de Saúde; 1996.

16. Sherlock IA. Ecological interactions of visceral leishmaniasis in the state of Bahia, Brazil. Mem Inst Oswaldo Cruz 1996; 91:671-683.

17. Alencar JE. Leishmaniose visceral no Brasil. Rev Assoc Med Bras 1958; 4:222-236

18. Resende MC, Camargo MCV, Vieira JRM, Nobi RCA, Porto MN, Oliveira CL, et al. Seasonal variation of Lutzomyia longipalpis in Belo Horizonte, State of Minas Gerais. Rev Soc Bras Med Trop 2006; 39:51-55

19. Almeida PS, Minzão ER, Minzão LD, Silva SR, Ferreira AD, Faccenda $O$, et al. Aspectos ecológicos de flebotomíneos (Diptera: Psychodidae) em área urbana do município de Ponta Porã, Estado de Mato Grosso do Sul. Rev Soc Bras Med Trop 2010; 43:723-727.

20. Silva EA, Andreotti R, Dias ES, Barros JC, Brazuna JCM. Detection of Leishmania DNA in phlebotomines captured in Campo Grande, Mato Grosso do Sul, Brazil. Exp Parasitol 2008; 119:343-348.

21. Oliveira ALL, Paniago AMM, Dorval MEC, Leal CR, Sanches M, Cunha RV, et al. Foco emergente de leishmaniose visceral em Mato Grosso do Sul. Rev Soc Bras Med Trop 2006; 39:446-450.

22. Glória MRB. Leishmaniose visceral: situação epidemiológica e distribuição espacial, município de Palmas, Tocantins. [Masters Dissertation].[Rio de Janeiro]: Escola Nacional de Saúde Pública Sergio Arouca; 2006. 98 p.

23. Carranza-Tamayo CO, Carvalho MSL, Bredt A, Bofil MIR, Rodrigues RMB, Silva AD, et al. Autochthonous visceral leishmaniasis in Brasília, Federal District, Brazil. Rev Soc Bras Med Trop 2010; 43:396-399.

24. Missawa NA, Borba JF. Leishmaniose visceral no município de Várzea Grande, Estado de Mato Grosso, no período de 1998 a 2007. Rev Soc Bras Med Trop 2009; 42:496-502

25. Badaró R, Jones TC, Lorenço R, Cerf BJ, Sampaio D, Carvalho EM, et al. A prospective study of visceral leishmaniasis in an endemic area of Brazil. J Infect Dis 1986; 154:639-649.

26. Queiroz MJA, Alves JGB, Correia JB. Leishmaniose visceral: características clínicoepidemiológicas em crianças de área endêmica. J. Pediatr (Rio J.) 2004; 80:141-146.

27. Alencar JE, Aragão T. Leishmaniose visceral no Ceará. Sintomas observados em 174 casos. Diagnóstico clínico. Paper presented at: XII Congresso Brasileiro de Higiene. Belém, PA, Brazil; 1955.

28. Pedrosa CMS, Rocha EMM. Aspectos clínicos e epidemiológicos da leishmaniose visceral em menores de 15 anos procedentes de Alagoas, Brasil. Rev Soc Bras Med Trop 2004; 37:300-304.

29. Pastorino AC, Jacob CMA, Oselka GW, Carneiro-Sampaio MMS. Leishmaniose visceral: aspectos clínicos e laboratoriais. J Pediatr 2002; 78:120-127.

30. Maia-Elkhoury ANS, Alves WA, Sousa-Gomes ML, Sena JM, Luna E. Visceral leishmaniasis in Brazil: trends and challenges. Cad Saude Publica 2008; 24: 2941-2947. 
31. Desjeux P, Alvar J. Leishmania/HIV co-infections: epidemiology in Europe. Ann Trop Med Parasitol 2003; 97:3-15.

32. Ministério da Saúde. Manual de recomendações para diagnóstico, tratamento e acompanhamento da co-infecção Leishmania-HIV. Brasília: Ministério da Saúde; 2004.

33. Jeronimo SMB, Oliveira RM, Mackay S, Costa RM, Sweet J, Nascimento ET, et al. An urban outbreak of visceral leishmaniasis in Natal, Brazil. Trans R Soc Trop Med Hyg 1994; 88:386-388.
34. Fernández-Guerreiro ML, Aguado JM, Buzon L, Barros C, Montalban C, Martin T, et al. Visceral leishmaniasis in immunocompromised hosts. Am J Trop Med 1987; 83:1098-1102.

35. Costa JML, Viana GMC, Saldanha ACR, Nascimento MDSB, Alvim AC, Burattini MN, et al. Leishmaniose visceral no estado do Maranhão, Brasil: a evolução de uma epidemia. Cad Saude Publica 1995; 11:321-324. 